\title{
Research onVocational Adaption of Novice Teacher in Kindergarten
}

\author{
Yuanyuan Li \\ Hangzhou College of Preschool Teacher Education \\ Zhejiang Normal University \\ Hangzhou, China 310012
}

\author{
Xiaomian Bai \\ Hangzhou College of Preschool Teacher Education \\ Zhejiang Normal University \\ Hangzhou, China 310012
}

\begin{abstract}
This research aimed to realize vocational adaption of novice teachers in kindergarten. 52 teachers who have been teaching for 0-3 years filled in the questionnaires. The results of the research revealed that (a)the occupational adaption was at an average level, which was reflected on the highest grade in environment occupational adaption and the lowest grade in ability of occupational skill; (b)on account of the level of mental vocational adaption, teachers hold lower career identity, but most of them reckoned that they were willing to stay with children; (c)from the perspective of skill vocational adaption, teacher had some difficulties in dealing with teaching and were poor in research ability; (d)according to vocational relationship adaption, teachers in coping with the relationship with children were better than parents and principal. Researchers put forward some effective recommendations on the basis of results, to promote the progress in preschool teachers' vocational adaption.
\end{abstract}

Keywords-novice teacher in kindergarten; vocational adaption; nvestigation

\section{INTRODUCTION}

In recent years, preschool education has been a highlighted topic. Several serious problems have been gradually exposed in early child education filed, such as admission hard, short of kindergarten teachers and demand exceed kindergarten supply etc. With the prosperity of social economy, renew of culture and transform of politics, parents pay more and more attention to their children's education. Teacher is the core of education, the destiny of educational enterprise depends on their specialization level. Recently, a large amount of surveys indicated that kindergarten teachers were confronted with various kinds of challenges at their beginning career, for example, teaching pressure, role exchange, environment change and complicated interpersonal relationship. Definitely, these factors increased the difficulty of vocational adaption. Therefore, it is necessary to discover and explore the vocational adaption condition of novice teacher in kindergarten to improve their adaption progress.

From existing studies, researchers found that most scholars explored issues in teachers' occupational adaption from the external environment perspective. For example, RalphFessler argued that all beginning teachers will encounter difficulties at start stage of their teacher career, the difficulty of occupation entry and role exchange was affected by the surrounding environment. The surrounding environment is consist of personality environment and organization environment. The influence of personality environment includes family factor, growth and development factor, personal character and hobbies. The influence of organization environment contains public trust and social expectation, rules and regulations in kindergarten, management mode, professional organizations and labor union. Domestic scholars Lijie Gao and Qing Lu considered that the main reasons for the serious loss of preschool teachers were their lower social status, exceed care and teaching pressure, heavy security responsibility and occupation burnout. In addition, Shaohua Chen deemed that the great pressure and responsibility they endured and the poor salary they got is the main reasons of kindergarten teacher frequency leave.

To a certain extent, those studies were contributed to inquire teachers' vocational adaption in kindergarten, but some defects still exist. The most notable one is that researchers just researched kindergarener from external environment, while ignored them as a independent individual who have specific psychology character. Moreover, majority of studies focused on primary and secondary school teaches, but few on kindergarten teachers. Because of diversity of service object, complexity of occupation relationship and specificity of occupation labor, novice teacher in kindergarten have more challenges to conquer at their entry stage. This study devotes to realize vocational adaption situation of novice teacher in kindergarten, to figure out deepen-causes of teacher run-off and to give out rational advises to advance teachers' vocational adaption process.

\section{METHODS}

\section{A. Design}

In order to know the situation of vocational adaption of novice teachers in kindergarten, researchers have referred to large number of literature and compiled a questionnaire on the basis of drawing other researcher' $s$ achievements, through which we got valid data.

\section{B. Participants}

Researcher sent questionnaires randomly to new preschool teachers who have working for 0-3 years, and 52 valid questionnaires were collected. Participants were differ in 
gender, teaching age, education background, major, and also differ in system and rating of kindergarten. "Table I"

TABLE I. PARTICIPANTS

\begin{tabular}{|l|l|l|l|}
\hline \multirow{4}{*}{ Gender } & \multicolumn{1}{|c|}{ Item } & Number & Percent(\%) \\
\hline \multirow{4}{*}{$\begin{array}{l}\text { Teaching } \\
\text { time }\end{array}$} & Male & 11 & 21.2 \\
\cline { 2 - 4 } & Female & 41 & 78.8 \\
\hline \multirow{4}{*}{$\begin{array}{l}\text { Education } \\
\text { background }\end{array}$} & $0-1$ & 33 & 63.5 \\
\cline { 2 - 4 } & $1-2$ & 10 & 19.2 \\
\cline { 2 - 4 } & $2-3$ & 9 & 17.3 \\
\cline { 2 - 4 } & Below collage degree & 0 & 0 \\
\cline { 2 - 4 } & College degree & 12 & 23.1 \\
\cline { 2 - 4 } & Undergraduate & 37 & 71.2 \\
\hline \multirow{5}{*}{ Major } & Postgraduate & 3 & 5.8 \\
\cline { 2 - 4 } & Preschool education & 44 & 84.6 \\
\cline { 2 - 4 } & Normal education & 6 & 11.5 \\
\cline { 2 - 4 } kystem of & Non-normal education & 2 & 3.9 \\
\hline \multirow{2}{*}{$\begin{array}{l}\text { Type of } \\
\text { kindergarten }\end{array}$} & Pubic & 41 & 78.8 \\
\cline { 2 - 4 } & Non-public & 11 & 21.2 \\
\cline { 2 - 4 } & $\begin{array}{l}\text { Demonstration } \\
\text { kindergarten }\end{array}$ & 8 & 15.4 \\
\cline { 2 - 4 } & Grade-1 kindergarten & 16 & 30.8 \\
\cline { 2 - 4 } & Grade-2 kindergarten & 12 & 23.1 \\
\cline { 2 - 4 } & non-grade kindergarten & 15 & 28.8 \\
\hline
\end{tabular}

\section{Material}

Researchers used questionnaire of vocational adaption of novice preschool teacher (which is drawing questionnaire of vocational adaption of novice teacher in kindergarten (Yiqi Qian,2009) to collect and analyze data. The questionnaire was divided into two parts: the first part is investigation for base information of beginning teacher from kindergarten, which contains information of gender, teaching age, education background, major, also system and rating of kindergarten. The second is inspection of newly qualified teacher' $s$ vocational adaption, which includes four evaluation dimensions: mental vocational adaption, skill vocational adaption, relative vocational adaption and environment vocational adaption.

\section{Procedures}

Researchers collected a body of related papers via searching Digital library, CNKI, then established the theoretical basis and drew out the questionnaire of vocational adaption of novice preschool teacher through sorting out and analyzing the papers. We give out our questionnaires to novice teachers who have working for 0-3 years in kindergarten. We put data in order after the questionnaires were taken back.

\section{E. Date Collection and Analysis}

The data was got by using the questionnaire of vocational adaption of novice preschool teacher. Then we put 52 valid collected results of researching into a database. The research used statistical analysis software SPSS17.0 to deal with data. The survey designs to explore current vocational adaption situation of beginning teacher in kindergarten and put forward corresponding countermeasures and suggestions.

\section{RESULTS}

\section{A. The Total Situation}

From four aspects (mental vocational adaption, skill vocational adaption, relationship vocational adaption and environment vocational adaption) to investigate vocational adaptation of novice preschool teacher, the results are presents in "Table II". The overall mean in every dimension was below 4 points. Compared results in four dimensions, the first leading was relationship vocational adaption (3.5596), followed by environment vocational adaption (3.4904), mental vocational adaption (3.4615), skill vocational adaption (3.4038) respectively. These data demonstrated that vocational adaptation of novice preschool teacher was below average level and had slightly difference. "Table II"

TABLE II. MEAN COMPARISONS FOR VOCATIONAL ADAPTION SITUATION OF NOVICE PRESCHOOL TEACHER

\begin{tabular}{|l|l|l|}
\hline & \multicolumn{1}{|c|}{ Mean } & Standard deviation \\
\hline Mental vocational adaption & 3.4615 & .77615 \\
\hline Skill vocational adaption & 3.4038 & .61201 \\
\hline $\begin{array}{l}\text { Relationship vocational } \\
\text { adaption }\end{array}$ & 3.5596 & .60432 \\
\hline $\begin{array}{l}\text { Environment vocational } \\
\text { adaption }\end{array}$ & 3.4904 & .70884 \\
\hline Total & 3.4753 & .41580 \\
\hline
\end{tabular}

- Novice teacher had a poor score in mental occupational adaption. Amount to $74.1 \%$ novice teacher engaged in preschool education industry is driven by theirs love. Meantime, there only $39.6 \%$ held that preschool teachers had higher social status and only $64.2 \%$ hoped to continue to embark preschool education industry. Data demonstrated that most of novice teachers had not realized preschool teacher is a lofty profession. Although they stepped into kindergarten driven by their ardently love, they still couldn't love both work and post.

- From the view of skill vocational adaption, teachers' vocational adaptation was at general level. In detail, they were good at dealing with teaching problem but worse at researching. According to questionnaire consequence, $92.4 \%$ novice teacher could device various educational methods direct at vary educational content and activity track. $86.8 \%$ could create effective teaching environment for learning. $86.7 \%$ could correctly understand educational goal and choose property teaching content meet children's demands. $81.1 \%$ could realize that researching is necessary for teaching, but only $67.9 \%$ knew how to write scientific article and research paper.

- Relationship vocational adaption data showed that adaptation of novice teacher common. 9.6\% could not pleasant to get along with children, $11.5 \%$ could not get along harmoniously with kindergarten leader. $11.5 \%$ could not deal well with parents. $15.4 \%$ could not harmoniously collaborate with their colleagues, 
$30.8 \%$ deemed that kindergarten have not supply comfortable working environment. Meantime, $42.3 \%$ dissatisfied with salary and social benefits. These data revealed that novice teacher has a preferable relationship with child but inferior with general social environment.

- From environment vocational adaption angle to analysis, $63.5 \%$ novice teacher thought that management in kindergarten was not democracy and in imperative to improve. $73.1 \%$ novice teacher considered that they were not offered enough economic support for learning and researching. All in all, novice teachers' vocational adaptation was in a ordinary condition.

\section{B. The Characteristic of Occupational Adaption of Novice Teacher in Kindergarten}

In order to explicitly explore character of occupational adaption of novice teacher in kindergarten, researchers analyzed and discussed respectively from sex, teaching age, official academic credentials, major, kindergarten system and kindergarten grade.

\section{Occupational Adaption Character of Different Gender Novice Preschool Teacher}

As "table III" showed that male vocational adaptation was slightly higher than female. Male was better adapted in mental and relationship vocational adaption than female, but worse than female in skill. In order to further clarify the difference level, researchers carried on the independence-samples $\mathrm{T}$ test for four dimensions "Table IV".

TABLE III. AVERAGE AND STANDARD DEVIATION OF VARY GENDER NOVICE TEACHER OCCUPATIONAL ADAPTION IN FOUR DIMENSIONS

\begin{tabular}{|c|c|c|c|c|c|c|}
\hline Gender & & $\begin{array}{c}\text { Mental } \\
\text { adaptation }\end{array}$ & $\begin{array}{c}\text { Skill } \\
\text { adaption }\end{array}$ & $\begin{array}{c}\text { Relationship } \\
\text { adaption }\end{array}$ & $\begin{array}{c}\text { Environment } \\
\text { adaption }\end{array}$ & total \\
\hline
\end{tabular}

As "table III" showed that male vocational adaptation was slightly higher than female. Male was better adapt in mental and relationship vocational adaption than female, but worse than female in skill. In order to further clarify the difference level, researchers carried on the independence-samples $\mathrm{T}$ test for four dimensions "Table IV".

TABLE IV. INDEPENDENT-SAMPLE T TEST OF OCCUPATIONAL ADAPTION IN DiFFERENT GENDER NOVICE PRESCHOOL TEACHER

\begin{tabular}{|c|c|c|c|c|c|c|}
\hline & \multicolumn{5}{|c|}{ Levene's Test for } \\
\hline & & \multicolumn{3}{|c|}{ Equality of Variances } & \multicolumn{2}{|c|}{ t-test for Equality of Means } \\
\hline & & $\mathrm{F}$ & Sig. & $\mathrm{t}$ & $\mathrm{df}$ & Sig.(2-tailed) \\
\hline Mental adaption & Equal variances assumed & 7.794 & .007 & 4.690 & 50 & .000 \\
\hline \multirow[t]{2}{*}{ Skill adaption } & Equal variances assumed & 2.949 & .092 & -5.360 & 50 & .000 \\
\hline & Equal variances not assumed & & & -7.03 & 25.996 & .000 \\
\hline $\begin{array}{l}\text { Relationship } \\
\text { adaption }\end{array}$ & Equal variances assumed & .520 & .474 & 3.661 & 50 & .001 \\
\hline \multirow{2}{*}{$\begin{array}{l}\text { Environment } \\
\text { adaption }\end{array}$} & Equal variances assumed & .533 & .469 & -.568 & 50 & .572 \\
\hline & Equal variances not assumed & & & -.491 & 13.472 & .631 \\
\hline \multirow[t]{2}{*}{ Total } & Equal variances assumed & 1.857 & .179 & .842 & 50 & .404 \\
\hline & Equal variances not assumed & & & 1.049 & 23.073 & .305 \\
\hline
\end{tabular}

As is shown above, there were significant difference in mental vocational adaption $(\mathrm{t}(50)=8.089, \mathrm{p}<0.05)$ and skill vocational adaption $(\mathrm{t}(50)=3.661, \mathrm{p}<0.05)$. Combined with statistic of average and standard deviation of vocational adaption in four dimensions, researchers found that male and female each had advantage in vocational adaption, male was better than female in mental adaption and female was better than male in skill adaption.

\section{Occupational Adaption Character Of Different Teaching} Age Novice Preschool Teacher

The mean and standard deviation showed that 1) teacher who had worked within one year got the lowest scores among the three groups divided by teaching age. 2) novice preschool teacher who had 1-2 years teaching age got highest scores 3)teacher having 2-3 years teaching age was at middle level. It means the level of novice teachers' vocational adaption did not accompany with the increase in teaching age. To further understand the weather the difference between three groups reached significant level, the data were analyzed for ANOVA using SPSS 17.0 software. "Table V" 
TABLE V. AVERAGE AND STANDARD DEVIATION OF OCCUPATIONAL ADAPTION IN FOUR DIMENSIONS

\begin{tabular}{|c|c|c|c|c|c|c|}
\hline Teaching age & & Mental adaption & $\begin{array}{c}\text { Skill } \\
\text { adaption }\end{array}$ & $\begin{array}{c}\text { Relationship } \\
\text { adaption }\end{array}$ & $\begin{array}{c}\text { Environment } \\
\text { adaption }\end{array}$ & total \\
\hline \multirow[t]{2}{*}{$0-1$ year } & $\mathrm{M}$ & 3.491 & 3.296 & 3.597 & 3.482 & 3.458 \\
\hline & SD & .741 & .534 & .578 & .733 & .405 \\
\hline \multirow[t]{2}{*}{$1-2$ years } & $\mathrm{M}$ & 3.280 & 3.958 & 3.130 & 3.670 & 3.531 \\
\hline & SD & .903 & .668 & .570 & .904 & .538 \\
\hline \multirow[t]{2}{*}{$2-3$ years } & $\mathrm{M}$ & 3.556 & 3.185 & 3.900 & 3.322 & 3.476 \\
\hline & SD & .822 & .507 & .510 & .249 & .339 \\
\hline \multirow[t]{2}{*}{ Total } & $\mathrm{M}$ & 3.462 & 3.404 & 3.560 & 3.490 & 3.475 \\
\hline & SD & .776 & .612 & .604 & .708 & .416 \\
\hline
\end{tabular}

The consequence of one-way ANOVA revealed that vocational adaption condition of different teaching age novice preschool teacher had significant difference in skill vocational adaption $(\mathrm{F}(2,51)=6.27, \mathrm{p}<0.05)$ and relationship vocational adaption $(\mathrm{F}(2,51)=4.582, \mathrm{p}<0.05)$. In order to clarify the causes of difference, researcher did a back-test "Table VI".

TABLE VI. ONE-WAY ANOVA OF VOCATIONAL ADAPTION OF NOVICE PRESCHOOl TEACHER Who Has DifFERENT TEACHING AGE

\begin{tabular}{|c|c|c|c|}
\hline $\begin{array}{c}\text { Mental } \\
\text { adaption }\end{array}$ & $\begin{array}{c}\text { Skill } \\
\text { adaption }\end{array}$ & $\begin{array}{c}\text { Relationship } \\
\text { adaption }\end{array}$ & $\begin{array}{l}\quad \text { Environ } \\
\text { ment } \\
\text { adaption }\end{array}$ \\
\hline F Sig. & F Sig. & F Sig. & $\begin{array}{l}\text { F } \\
\text { Sig. }\end{array}$ \\
\hline $.357 \quad .704$ & $6.270 \quad .004$ & $\begin{array}{ll}4.582 \quad .015\end{array}$ & $.571^{.567}$ \\
\hline
\end{tabular}

"Table VII" showed that the skill vocational adaptability of new qualified teacher had significant difference in 0-1 year and $1-2$ years $(\mathrm{p}<0.05)$, also has significant difference in $1-2$ years and $2-3$ years $(\mathrm{p}<0.05)$. But on obvious difference was found in 0-1 years and 2-3 years. The reason of this kind of circumstance may lack of subjects who has 2-3 teaching age probably.
TABLE VII BACK-TEST ON SKILL VOCATIONAL ADAPTION AND RELATIONSHIP ADAPTION OF NOVICE PRESCHOOL TEACHER WHO ARE DIFFERENT IN TEACHING AGE

\begin{tabular}{|c|c|c|c|c|}
\hline & & $\begin{array}{c}\text { Teaching } \\
\text { age }\end{array}$ & $\begin{array}{c}\text { Teaching } \\
\text { age }\end{array}$ & Sig. \\
\hline \multirow{3}{*}{$\begin{array}{l}\text { Skill } \\
\text { adaption }\end{array}$} & LSD & $0-1$ & $1-2$ & .002 \\
\hline & & & $2-3$ & .601 \\
\hline & & $1-2$ & $2-3$ & .004 \\
\hline \multirow{3}{*}{$\begin{array}{l}\text { Relations } \\
\text { hip } \\
\text { adaption }\end{array}$} & LSD & $0-1$ & $1-2$ & .027 \\
\hline & & & $2-3$ & .161 \\
\hline & & $1-2$ & $2-3$ & .005 \\
\hline
\end{tabular}

The difference of relationship vocational adaptability of new qualified teacher who had engaged in preschool education industry $1-2$ years and 2-3 years at edge obvious $(\mathrm{p}=0.05)$.

\section{E. Vocational Adaption Character of Novice Preschool Teacher with Different Educational Background}

The accurate numeral in "Table VIII" illustrated that vocational adaptation of new qualified teacher with junior college credential near to the teacher with undergraduate credential, postgraduate credential teacher slightly higher than junior college and undergraduate teacher.

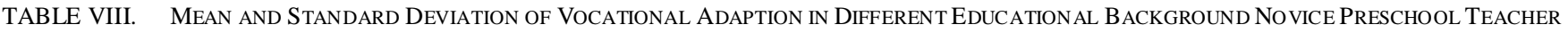

\begin{tabular}{|c|c|c|c|c|c|c|}
\hline & & Mental adaption & Skill adaption & Relationship adaption & Environment adaption & Total \\
\hline \multirow[t]{2}{*}{ Junior college } & $\mathrm{M}$ & 3.291 & 3.673 & 3.458 & 3.466 & 3.482 \\
\hline & SD & .944 & .714 & .673 & .780 & .544 \\
\hline \multirow[t]{2}{*}{ Undergraduate } & M & 3.440 & 3.299 & 3.554 & 3.478 & 3.436 \\
\hline & SD & .693 & .568 & .561 & .673 & .347 \\
\hline \multirow[t]{2}{*}{ Postgraduate } & M & 4.400 & 3.611 & 4.033 & 3.733 & 3.928 \\
\hline & SD & .556 & .481 & .874 & 1.097 & .526 \\
\hline \multirow[t]{2}{*}{ Total } & M & 3.475 & 3.404 & 3.560 & 3.490 & 3.475 \\
\hline & SD & .776 & .612 & .604 & .709 & .416 \\
\hline
\end{tabular}

TABLE IX ONE-WAY ANOVA ON OCCUPATIONAL ADAPTION CONDITION OF DIFFERENT EDUCATIONAL BACKGROUND NOVICE PRESCHOOL TEACHER

\begin{tabular}{|c|c|c|c|}
\hline $\begin{array}{c}\text { Mental } \\
\text { adaption }\end{array}$ & $\begin{array}{c}\text { Skill } \\
\text { adaption }\end{array}$ & $\begin{array}{c}\text { Relationship } \\
\text { adaption }\end{array}$ & $\begin{array}{c}\text { Environment } \\
\text { adaption }\end{array}$ \\
\hline F Sig & F $\quad$ Sig & $\begin{array}{ll}\text { F } & \text { Sig }\end{array}$ & $\begin{array}{ll}\text { F } & \text { Sig }\end{array}$ \\
\hline $2.656 \quad .080$ & $1.944 \quad .154$ & $\begin{array}{ll}1.096 & .342\end{array}$ & $.182 \quad .834$ \\
\hline
\end{tabular}

academic credential had not significant difference in four dimensions. The result was against previous surveys, which may induced by maldistribution of subjects in academic credential (postgraduate credential teacher only occupied $6.3 \%$ ). Therefore, the teachers' highest academic credential weather influence the character of vocational adaption is still have to be researched.

The character of occupational adaption of different major novice preschool teacher is shown in "Table IX". 
TABLE X. Mean and Standard DeViation of Vocational Adaption in Different Major Novice Preschool Teacher

\begin{tabular}{|c|c|c|c|c|c|c|}
\hline Major & & $\begin{array}{c}\text { Skill } \\
\text { adaption }\end{array}$ & $\begin{array}{c}\text { Skill } \\
\text { adaption }\end{array}$ & $\begin{array}{c}\text { Relationship } \\
\text { adaption }\end{array}$ & Environment adaption & Total \\
\hline Preschool education & SD & .729 & .608 & .574 & .717 & .403 \\
\hline Non-preschool education & M & 3.477 & 3.390 & 3.571 & 3.460 & 3.470 \\
\hline \multirow[t]{4}{*}{ Total } & SD & 1.053 & .669 & .793 & .680 & .512 \\
\hline & M & 3.375 & 3.479 & 3.500 & 3.663 & 3.503 \\
\hline & SD & .776 & .612 & .604 & .709 & .416 \\
\hline & $\mathrm{M}$ & 3.462 & 3.404 & 3.556 & 3.490 & 3.475 \\
\hline
\end{tabular}

As mean and standard deviation showed above, the vocational adaptability had not significant difference between preschool educational major and non-preschool educational major. In addition, the adaptability of new qualified teacher with non-preschool educational major background was slightly better than preschool educational major teacher as shown in "Table X".

TABLE XI. IndEPENDENCE SAMPLE T TeSt OF OCCUPATION AdAPTION IN DIFFERENT MAJOR BACKGRound Novice PRESCHOOL TEACHER

\begin{tabular}{|c|c|c|}
\hline & & $\begin{array}{l}\text { Levene's Test for } \\
\end{array}$ \\
\hline & & Equality of Variances t-test for Equality of Means \\
\hline & & $\begin{array}{lllll}\text { F } & \text { Sig. } & \text { t } & \text { df } & \text { Sig.(2-tailed) }\end{array}$ \\
\hline $\begin{array}{l}\text { Mental } \\
\text { adaption }\end{array}$ & $\begin{array}{l}\text { Equal variances assumed } \\
\text { Equal variances not assumed }\end{array}$ & $\begin{array}{lllll}4.267 & .044 & .340 & 50 & .735 \\
& .263 & 8.262 & .799\end{array}$ \\
\hline Skill adaption & $\begin{array}{l}\text { Equal variances assumed } \\
\text { Equal variances not assumed }\end{array}$ & $\begin{array}{ccccc}.419 & .521 & -. .375 & 50 & .709 \\
& -.351 & 9.227 & .734\end{array}$ \\
\hline $\begin{array}{l}\text { Relationship } \\
\text { adaption }\end{array}$ & $\begin{array}{l}\text { Equal variances assumed } \\
\text { Equal variances not assumed }\end{array}$ & $\begin{array}{ccccc}.951 & .334 & .301 & 50 & .765 \\
& & .240 & 8.388 & .816 \\
\end{array}$ \\
\hline $\begin{array}{l}\text { Environment } \\
\text { adaption }\end{array}$ & $\begin{array}{l}\text { Equal variances assumed } \\
\text { Equal variances not assumed }\end{array}$ & $\begin{array}{ccccc}.050 & .824 & -.743 & 50 & .461 \\
& -.771 & 10.047 & .458 \\
\end{array}$ \\
\hline total & $\begin{array}{l}\text { Equal variances assumed } \\
\text { Equal variances not assumed }\end{array}$ & $\begin{array}{ccccc}.054 & .817 & -.203 & 50 & .840 \\
& & -.172 & 8.647 & .868 \\
\end{array}$ \\
\hline
\end{tabular}

Independent-sample $\mathrm{T}$ test displayed that the adaptability of difference major background novice preschool teacher had not significant difference, the possible reason for this circumstance was lesser sample capacity of non-preschool education major background as shown in "Table XI".

\section{F. The Character Of Occupational Adaption Of Novice Preschool Teacher In Different Kindergarten System}

"Table XII" showed that new preschool teachers from pubic kindergarten adapted well than the non-public.It reflected in relationship adaption, skill adaption and environment adaption, but not in mental adaption.

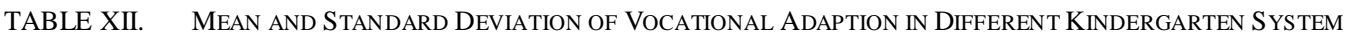

\begin{tabular}{lllllcc}
\hline $\begin{array}{c}\text { Kindergarten } \\
\text { system }\end{array}$ & Skill adaption & Skill adaption & $\begin{array}{c}\text { Relationship } \\
\text { adaption }\end{array}$ & $\begin{array}{c}\text { Environment } \\
\text { adaption }\end{array}$ & Total \\
\hline Public & M & 3.444 & 3.422 & 3.622 & 3.505 & 3.495 \\
& SD & .722 & .569 & .564 & .687 & .382 \\
Non-public & M & 3.527 & 3.333 & 3.327 & 3.436 & 3.403 \\
& SD & .989 & .778 & .718 & .817 & .537 \\
Total & M & 3.475 & 3.404 & 3.559 & 3.490 & 3.475 \\
& SD & .416 & .612 & .604 & .709 & .416 \\
\hline
\end{tabular}

Independent-sample test showed that different kindergarten systems had not significant difference in each dimensions. "Table XIII" 
TABLE XIII. INDEPENDENCE SAMPLE T TEST OF OCCUPATION ADAPTION IN DIFFERENT KINDERGARTEN SYSTEM

\begin{tabular}{|c|c|c|c|c|c|c|}
\hline & & \multicolumn{5}{|c|}{$\begin{array}{l}\text { Levene's Test for } \\
\end{array}$} \\
\hline & & \multicolumn{3}{|c|}{ Equality of Variances } & \multicolumn{2}{|c|}{ t-test for Equality of Means } \\
\hline & & $\mathrm{F}$ & Sig. & $\mathrm{t}$ & df & Sig.(2-tailed) \\
\hline $\begin{array}{l}\text { Mental } \\
\text { adaption }\end{array}$ & $\begin{array}{l}\text { Equal variances assumed } \\
\text { Equal variances not assumed }\end{array}$ & 4.139 & .047 & $\begin{array}{l}-.314 \\
-.261\end{array}$ & $\begin{array}{c}50 \\
13.002\end{array}$ & $\begin{array}{l}.755 \\
.798\end{array}$ \\
\hline Skill adaption & $\begin{array}{l}\text { Equal variances assumed } \\
\text { Equal variances not assumed }\end{array}$ & .496 & .484 & $\begin{array}{l}.427 \\
.356\end{array}$ & $\begin{array}{c}50 \\
13.014\end{array}$ & $\begin{array}{l}.671 \\
.727\end{array}$ \\
\hline $\begin{array}{l}\text { Environment } \\
\text { adaption }\end{array}$ & $\begin{array}{l}\text { Equal variances assumed } \\
\text { Equal variances not assumed }\end{array}$ & .494 & .486 & $\begin{array}{l}.282 \\
.255\end{array}$ & $\begin{array}{c}50 \\
14.026\end{array}$ & $\begin{array}{l}.779 \\
.803\end{array}$ \\
\hline total & $\begin{array}{l}\text { Equal variances assumed } \\
\text { Equal variances not assumed }\end{array}$ & 1.266 & .266 & $\begin{array}{l}.649 \\
.534 \\
\end{array}$ & $\begin{array}{c}50 \\
12.834 \\
\end{array}$ & $\begin{array}{l}.519 \\
.602 \\
\end{array}$ \\
\hline
\end{tabular}

\section{G. The Character Of Occupational Adaption Of Novice}

Preschool Teacher In Different Kindergarten Type

What "table XIV" presented was that different kindergarten type slightly influenced teachers' vocational adaption. Teachers from Grade-2 kindergarten adapted well than other three kindergarten types, which reflected in mental and relationship adaptation. Researchers thought that high working pressure in demonstration kindergarten and Grade-1 kindergarten may account for the reason.

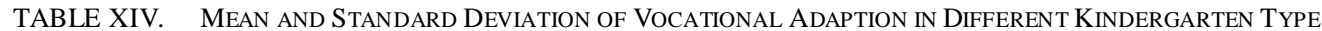

\begin{tabular}{|c|c|c|c|c|c|c|}
\hline Kindergarten type & & Skill adaption & Skill adaption & $\begin{array}{c}\text { Relationship } \\
\text { adaption }\end{array}$ & $\begin{array}{c}\text { Environment } \\
\text { adaption }\end{array}$ & Total \\
\hline \multirow{2}{*}{$\begin{array}{l}\text { Demonstration } \\
\text { kindergarten }\end{array}$} & M & 3.300 & 3.489 & 3.263 & 3.300 & 3.345 \\
\hline & S D & .968 & .633 & .639 & .906 & .624 \\
\hline Grade-1 & M & 3.368 & 3.302 & 3.718 & 3.769 & 3.528 \\
\hline kindergarten & SD & .815 & .653 & .621 & .682 & .447 \\
\hline Grade-2 & $\mathrm{M}$ & 3.858 & 3.298 & 3.833 & 3.533 & 3.615 \\
\hline kindergarten & SD & .496 & .571 & .571 & .692 & .222 \\
\hline no professional titles & M & 3.340 & 3.527 & 3.320 & 3.240 & 3.365 \\
\hline \multirow[t]{3}{*}{ Total } & SD & .801 & .633 & .500 & .600 & .371 \\
\hline & M & 3.464 & 3.397 & 3.557 & 3.484 & 3.472 \\
\hline & SD & .783 & .616 & .610 & .714 & .419 \\
\hline
\end{tabular}

The consequence of one-way ANOVA revealed that relationship vocational adaption $(\mathrm{F}=2.859, \mathrm{P}<0.05)$. In vocational adaptation of novice preschool teacher who came from different kindergarten type had significant difference in order to clarify the causes of difference, researchers did a back-test "Table XV".

TABLE XV. ONe-Way ANOVA of Vocational Adaption of Novice Preschool Teacher Who Come From DifFERENT KindERGARTEN TyPe

\begin{tabular}{|c|c|c|c|c|}
\hline & Mental adaption & Skill adaption & $\begin{array}{l}\text { Relationship } \\
\text { adaption }\end{array}$ & $\begin{array}{c}\text { Environment } \\
\text { adaption }\end{array}$ \\
\hline $\begin{array}{l}\text { kindergarten } \\
\text { type }\end{array}$ & $\begin{array}{l}\text { F Sig } \\
1.363 \quad .266\end{array}$ & $\begin{array}{l}\text { F } \quad \text { Sig } \\
.499 \quad .685\end{array}$ & $\begin{array}{l}\text { F Sig } \\
2.859 \quad .047\end{array}$ & $\begin{array}{l}\text { F Sig } \\
1.694 \quad .181\end{array}$ \\
\hline
\end{tabular}

"Table XVI" showed that demonstration kindergarten's teacher had no significant difference between grade-1 kindergarten and non-grade kindergarten $(p<0.05)$, but had significant difference with grade-2 kindergarten $(\mathrm{p}<0.05)$. Grade-1 kindergarten had no significant difference with grade-2 kindergarten and non-grade kindergarten $(\mathrm{p}>0.05)$. Grade-2 kindergarten had significant difference with nongrade kindergarten $(\mathrm{p}<0.05)$.

TABLE XVI. Back-Test on Relationship Vocational Adaption of Novice Preschool Teacher Who ARe From Different Kindergarten Type

\begin{tabular}{llll}
\hline \multicolumn{1}{c}{ kindergarten type } & \multicolumn{1}{c}{ kindergarten type } & Sig. \\
\hline LSD & Demonstration kindergarten & Grade-1 kindergarten & .075 \\
& & Grade-2 kindergarten & .036 \\
& Grade-1 kindergarten & non-grade kindergarten & .821 \\
& Grade-2 kindergarten & .606 \\
& Grade-2 kindergarten & non-grade kindergarten & .061 \\
& & non-grade kindergarten & .027 \\
\hline
\end{tabular}




\section{DISCUSSION AND SUGGESTION}

The research concluded that there were some problems existed in new preschool teacher vocational adaption.

- The total situation of vocational adaption was not optimistic. Score 5 was defined datum line of excellent and score 4 was confirmed datum line of good, while through One Sample T-Test we found that the average scores of vocational adaption $(3.48 \pm 0.42)$ was lower than score 4 , it had reached statistically significant differences $(\mathrm{t}=-5.00--7.02, \mathrm{p}<0.05)$. So, we judged that the general level of new preschool teacher vocational adaption was relatively low.

- There were some difficulties for new preschool teachers to adapt vocation in different aspects. In the dimension of mental vocational adaption, the social status of preschool education teachers could hardly won the approval of new novice teacher. And in the dimension of skill vocational adaption, it showed that the outstanding problem was low capacity of research. While the hardest point in the dimension of relationship vocational adaption was teachers ' unsatisfactory with salary. Kindergarten did not provide enough support to new teachers was the most outstanding problem. All of above problems showed that some effective measures should be taken to solve such problems. Researchers tried to propose some suggestions from teachers, training institutions, kindergartens and government.

- Novice preschool teacher should built sense of selfregulation. One source of unable vocational adaption is the gap between the subjective expectations and the objective reality. It requires teachers to have a correct understanding of the contradiction between ideal and reality, to do a comprehensive evaluation and judgment, to establish positive attitude towards the world, the life, and to set a clear vocation goals. Additionally, because of the particularity of children, teachers should get rid of being emotional and keep a nice mood everyday. But it is difficult to stay good condition all the time, so teachers would better find some ways to relieve their pressures, such as share feeling with others, write a diary.

- University should optimize training strategy before students enter into vocation. Vocation training is an important part of teacher career. When new preschool teachers begin career, the most serious problem is that theory come apart of practice. So, university should increase interaction with kindergarten, which can provide more chance for students touching with child and putting theory into practice.

- Kindergarten should build harmonious culture. As a new member, novice preschool teachers signify vigor and vitality, they ought to be respected and taken care. Kindergarten leader should try to stimulate new preschool teachers' potential and listen to their voice. Also, Kindergarten should provide protection for new preschool teachers to learn and do research. Working in a comfortable and helpful environment, we believe that teachers can develop well and soon.

- Government should grant funding for policy support to preschool teachers. Presently, the proportion of preschool-funding is low among the total education budget, which results low-income of preschool teachers. The increase investment in early childhood education can help to solve this problem directly and improve teachers' social status.

\section{REFERENCES}

[1] Bick-har Lam(2014).Challenges Beginning Teachers Face in Hong Kong.Schools: Studies in Education, 11, 156-169

[2] GAO Lijie, LU Qing(2011). Crisis of Preschool Teacher Losing and Its Causes Analysis. The Guide of Science \& Education

[3] Linda Haggartya., Keith Postlethwaiteb., Kim Diment Jean Ellinsa.(2011). British Educational Research Journal, 37, 935-954

[4] Wang Jing(2014).Research on the Vocational Adaptation Characteristics and the Correlated Influence Factors of Beginning Teachers in Nursery Schools.Professional Master Degree Dissertation.Tianjin Normal University.

[5] Qian Yiqi(2009).The Study of kindergarten Beginning Teacher's Entry Adaptation.Thesis for Master Degree.East China Normal University. 